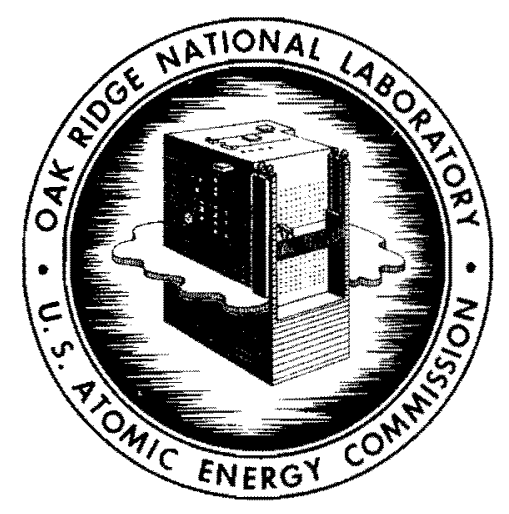

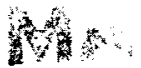 \\ OAK RIDGE NATIONAL LABORATORY \\ operated by \\ UNION CARBIDE CORPORATION
}

UNION

for the

U.S. ATOMIC ENERGY COMMISSION

$$
\text { ORNL-TM-249- }(\mathrm{V})
$$

\title{
TESTS OF BEARING MATERIALS FOR THE EXPERIMENTAL THROUGH-TUBES IN THE EGCR
}

R. E. MacPherson

A. M. Smith

\section{NOTICE}

This document contains information of a preliminary nature and was prepared primarily for internal use at the Oak Ridge National Laboratory. It is subiect to revision or correction and therefore does not represent a final report. The information is not to be abstracted, reprinted or otherwise given public dissemination without the approval of the ORNL patent branch, Legal and Information Control Department. 
This report was prepored as an account of Government sponsored work. Neither the United Stotes, nor the Commissian, nor any person acting on behalf of the Commission:

A. Makes any warronty or representation, expressed or implied, wh respect to the oecuracy, completeness, or usetulness of the information contained in this report, or that the use of ony information, apparatus, method, or pracess disclosed in this report may not infringe privately owned rights; or

B. Assumes ony liobilities with respect to the use of or for domages resulting trom the use of any information, apparatus, method, or process disclosed in this report.

As used in the above, "person acting on behalf of the Commission" includes any emplayee of cantractor of the Commission, or employe of such controctor, to the extent that such employe or contractor of the Commission, or employee of such contractor prepares, disseminates, or provides access to, any intormation pursuant to his employment or contract with the Commission, or his employment with such conteactor. 
Contract No. W-7405-eng-26

Reactor Division

TESTS OF BEARING MATERIALS FOR THE EXPERIMENTAL

THROUGH-TUBES INT THE EGCR

R. E. MacPherson A. M. Smith

DATE ISSUED

JUL 161962

OAK RIDGE NATIONAL LABORATORY

Oak Ridge, Tennessee

operated by

UNION CARBIDE CORPORATION

for the

U.S. ATOMIC ENERGY COMMISSION 
, 
ABSTRACT

The four experimental through-tubes provided in the Experimental GasCooled Reactor will extend directly through the core of the reactor and penetrate both the upper and lower pressure vessel heads. Each tube is anchored in an upper head nozzle and the bottom end is allowed to slide in a lower head nozzle. This lower nozzle is basically a "T" section that provides bottom access to the through-tube and a side access for the piping which connects the through-tube to the experimenter's cell. Due to differential thermal expansion of the through-tubes relative to the reactor pressure vessel, vertical movement of the through-tube within the " $T$ " section will be experienced. At the same time a horizontal thrust applied to each tube by thermal expansion of the piping to the experimental cell will result in metal-to-metal contact between each tube and the lower "T" section. Tests have been conducted on three types of bearing material proposed for use on the through-tubes and "T" sections to minimize galling which can be expected to occur. Stellite No. 12 has been demonstrated to be an adequate bearing material for the intended application. 
Introduction

The Experimental Gas-Cooled Reactor is to be equipped in the future with four independent gas-cooled, in-pile loops. One feature of each loop is a through-tube which extends completely through the EGCR core and penetrates the upper and lower pressure vessel heads within appropriate nozzles ${ }^{l}$ attached to the reactor vessel. This through-tube is anchored in an upper head nozzle, and the lower end of the tube slides in a lower head nozzle which is basically a "T" section. As shown in Figure 1, the "T" provides access at the bottom to the length of the through-tube and a side access for the piping which connects the in-pile section to the experimental equipment cell.

During operation of the EGCR, the experimental through-tubes in the reactor will move vertically in the lower " $T$ " section of the reactor due to differential thermal expansion of the tubes relative to the reactor pressure vessel. At the same time a horizontal thrust applied to each tube by thermal expansion of the lower chase piping will force the o.d. of the tube against the $i . d$. of the "T" section. Consequently, it is desirable to have the mating surfaces of each tube and lower "T" section plated with a bearing material that will reduce the galling which can be expected to occur. It is also desirable to have materials which will not exhibit self-welding tendencies during extended periods when the reactor is at steady-state conditions.

Figure 2 shows schematically the thrust loads and bending moments anticipated on the experimental through-tube during normal operation ${ }^{2}$. Also shown is the method by which the maximum reaction was simulated during the test program. It should be noted that there is point contact between the two test pieces when unloaded and that, when the moving shaft is in the right-hand position, the load on the bearing area increases to $3150 \mathrm{lbs}$.

$I_{F}$. H. Neill and C. Michelson, EGCR Experimental Loops Preliminary Design Report, ORIL TM-134, March 27, 1962.

${ }^{2}$ EGCR Experimental Loop Design Analyses, ORNL CF-61-6-4, January 5, 1962. 


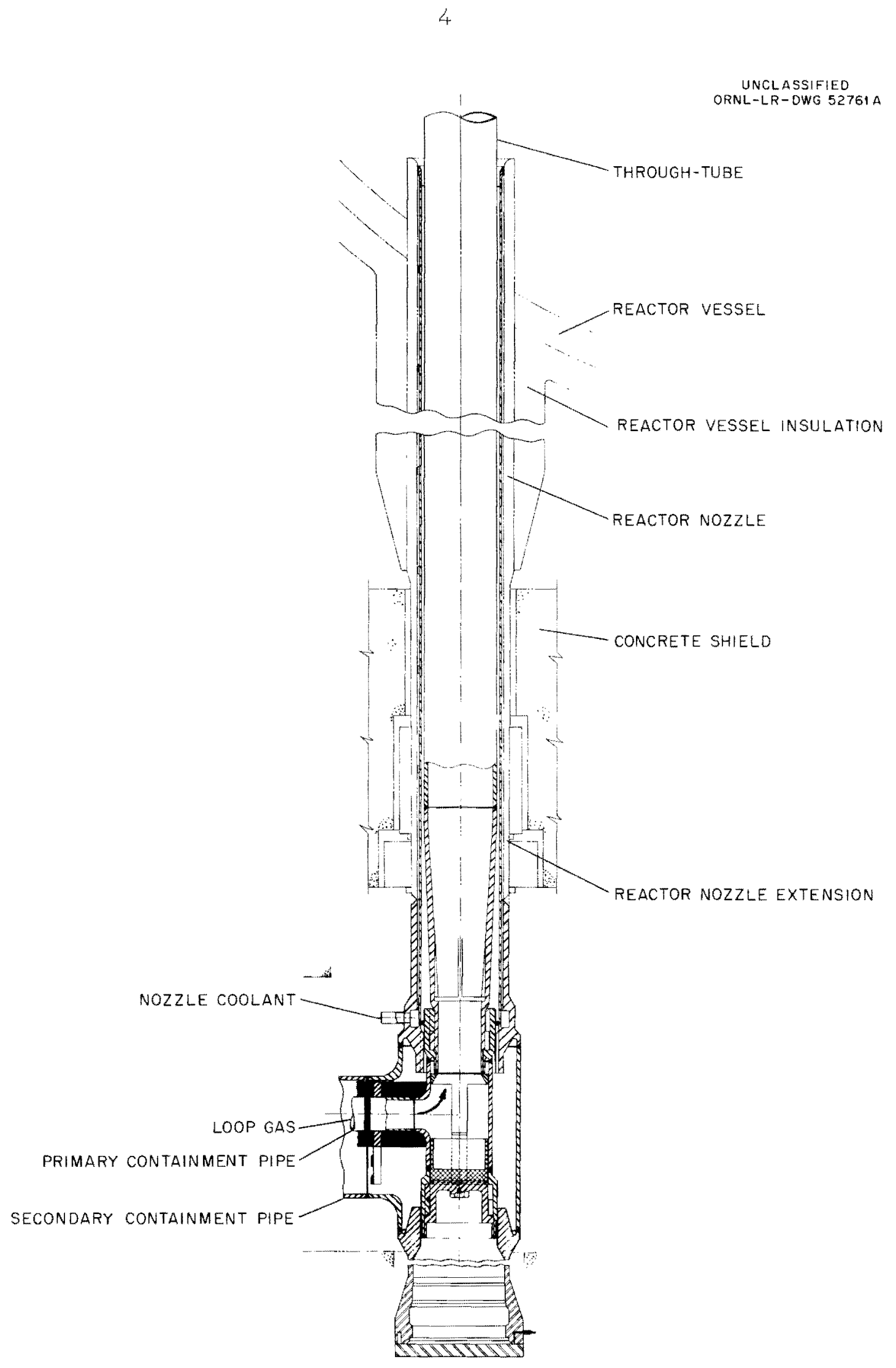

Fig. 1. Bottom Nozzle Tee Section. 


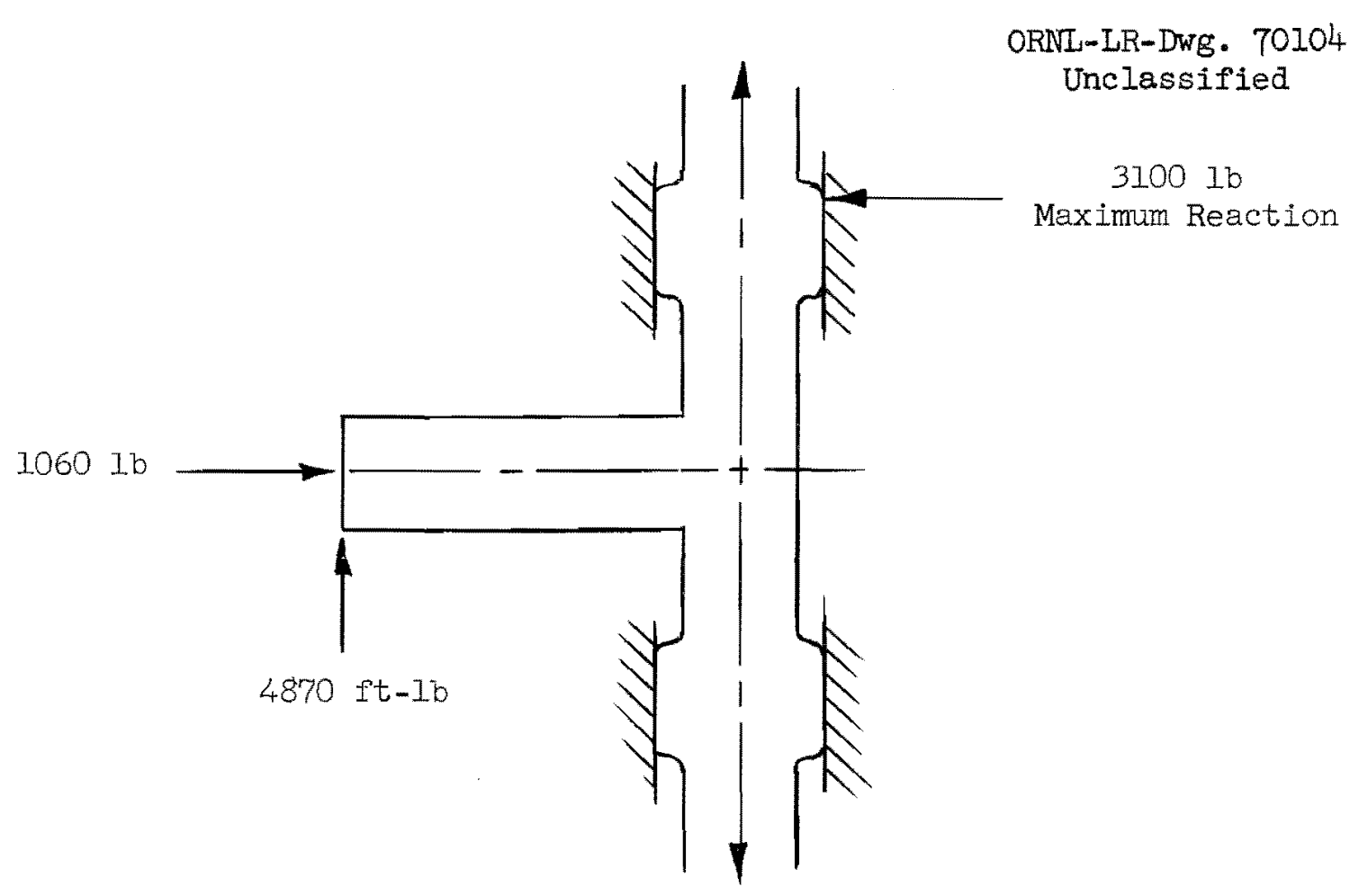

Fig. 2.a. Through-Tube Bearing in Lower "T" Section.

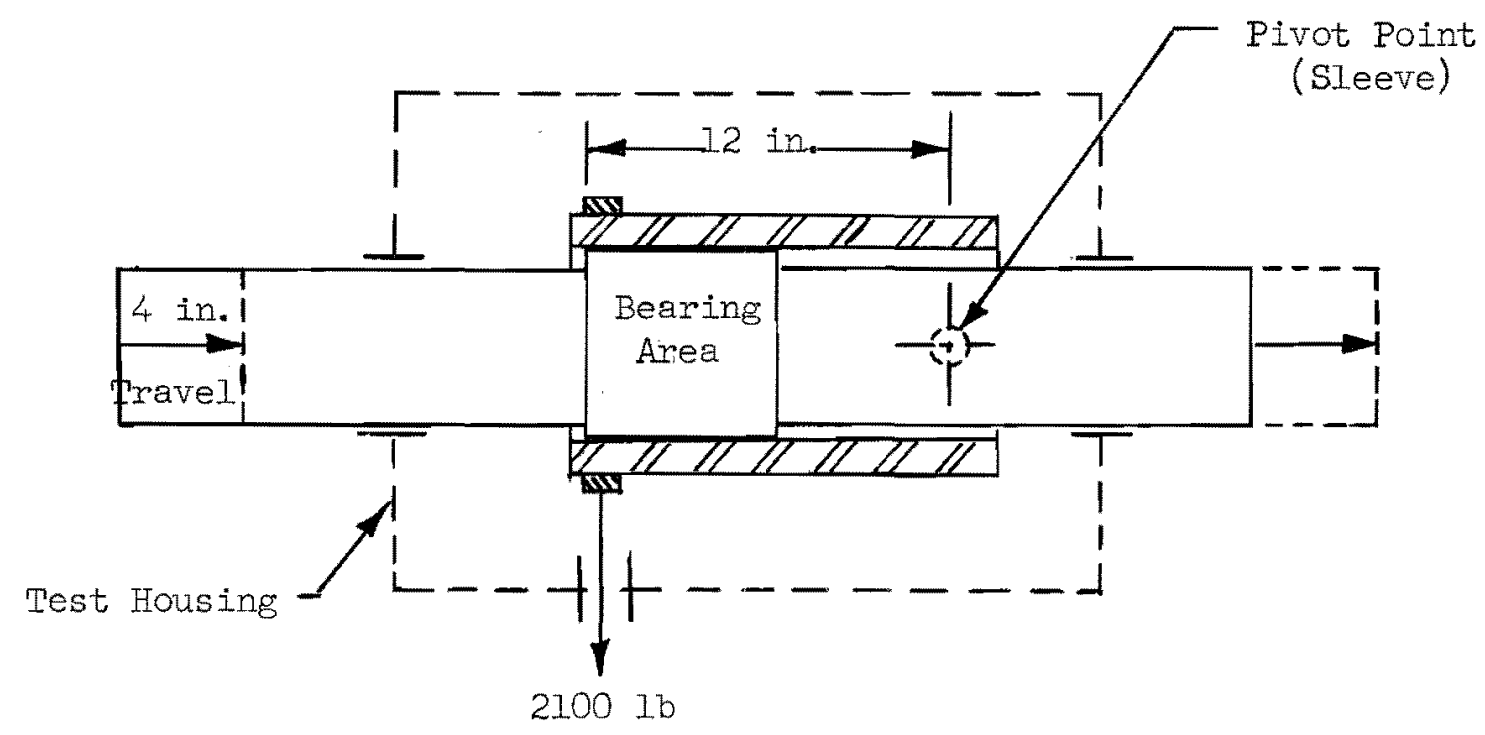

Fig. 2.b. Through-Tube Bearing Mockup (Maximum Reaction 3150 lb). 
Summary

The purpose of this test was to determine the galling and selfwelding tendency of various bearing materials proposed for the experimental through-tube and lower " $T$ " section when subjected to operating conditions similar to those anticipated in the EGCR experimental loop facility. Because of the proposed bearing geometry and the thrust and bending loads imposed thereon, it was apparent that some degree of galling of the bearing surfaces must be expected. This problem becomes more critical in view of the fact that both bearing surfaces are permanently installed and must remain functional during the life of the reactor.

Six tests were conducted using three types of bearing material. These materials, selected as a result of a literature survey on various bearing materials ${ }^{3}$, were Stellite No. 6, Stellite No. 12, and Linde Flame-Plate LW-IN30. In each test the simulated through-tube bearing and lower "T" section sleeve, plated with the same type material, were first subjected to a mechanical cycling test consisting of 1000 cycles over a four-inch stroke. This is roughly equivalent to the service seen by the reactor installation if there were one reactor shutdown per week during a twenty-year reactor life. If a material surface completed a 1000-cycle test, a static load test was applied to determine any self-welding tendency of the parts. All tests were carried out in a helium atmosphere with parts heated to $950^{\circ} \mathrm{F}$. The load carried by the parts remained constant (no allowance was made for creep relaxation of the lower chase piping when held at reactor operating conditions) for each entire test and was such that the maximum reaction at one end of the four-inch stroke was the same as calculated for the actual reactor application. The load at the other end of the stroke was two-thirds of the maximum, whereas in the reactor (again neglecting creep) this load would be zero.

\footnotetext{
3etter from R. E. Helms to R. E. MacPherson, November 8, 1960.
} 
The test program demonstrated that the bearing combination of Stellite 12 against Stellite 12 was the most suitable material for the intended application. This hard facing material was readily applied to the bearing surfaces of the test pieces and survived the test program without an objectionable degree of galling. There was no terdency of the two surfaces to self-weld when maintained under a representative static losd at reactor operating conditions for a fiveweek period.

Stellite 6, a softer material thax Stellite 12, was found to be less resistant to galling in helium at $950^{\circ} \mathrm{F}$, even at somewhat lower loadings. Lirde Flame-Plate LW-IN30 was completely unsatisfactory due to extensive cracking and flaking of the hard-facing. During tests of both the Stellite 6 combination and the Linde Flame-Plate combination, there was no tendency of the bearing surfaces to selfweld during one week static load tests.

Test Equipment

1) A simulated through-tube bearing (hereafter referred to as the "plug") was fabricated from $7 \mathrm{in.} \mathrm{diameter,} \mathrm{type} 304$ stainless steel bar stock approximately $8 \mathrm{l} / 2 \mathrm{in.}$ long. The rough machined diameter of the $51 / 2$ in. long bearing surface of the plug varied with the individual test to accommodate the desired bearing material thickness. After the cearing material was added, the plug was finished to $6.999 \pm .001$ in. outside diameter.

2) The simulated "T" section bearing (hereafter referred to as the "sleeve") was fabricated from an $8 \mathrm{in.} 0 . \mathrm{d}$. by .625 wall tube approximately $14 \mathrm{in.}$. Iong and was fitted with a yoke and pivot pins. The yoke was connected to the desired weight and used to trensmit the load to the sleeve and plug while the pivot pins permitted a minor rotation of the sleeve as the plug was cycled over the 4 in. travel. Bearing material was applied to the $i . d$ of the sleeve over a 7 in. length and then finished to a $7.029 \pm .001$ i.d. to provide a desired radial clearance of 14 to $16 \mathrm{mils}$. Two thermocouples were installed on the outside surface of the sleeve. 
3) Two plug extensions were machined to attach to the threaded portion of the plug (Figure 3). Each extension was fitted with a calrod heater and thermocouples (Figure 4) which were used to heat and measure the temperature of the ends of the plug. Cooling channels were provided in each extension to conduct the heat away from the main body of the extensions and prevent the area in contact with the journal bearings in the main housing from becoming overheated.

4) The main housing enclosed the plug and sleeve. Flanges on either end of the housing contained a bronze journal bearing which supported the plug extensions and provided for axial movement of the plug in the fixed sleeve.

5) Two Model B-54XW Conoflow operators were attached to the plug extensions to provide the necessary thrust to cycle the plug when the required weight was added to the sleeve.

6) Gas taps were provided on the housing for filling and sampling the helium atmosphere. The necessary heaters and thermocouples were installed on the housing for maintaining the test environment at $950^{\circ} \mathrm{F}$. The completed assembly, support structure and necessary auxiliary equipment are shown in rigure 5. 

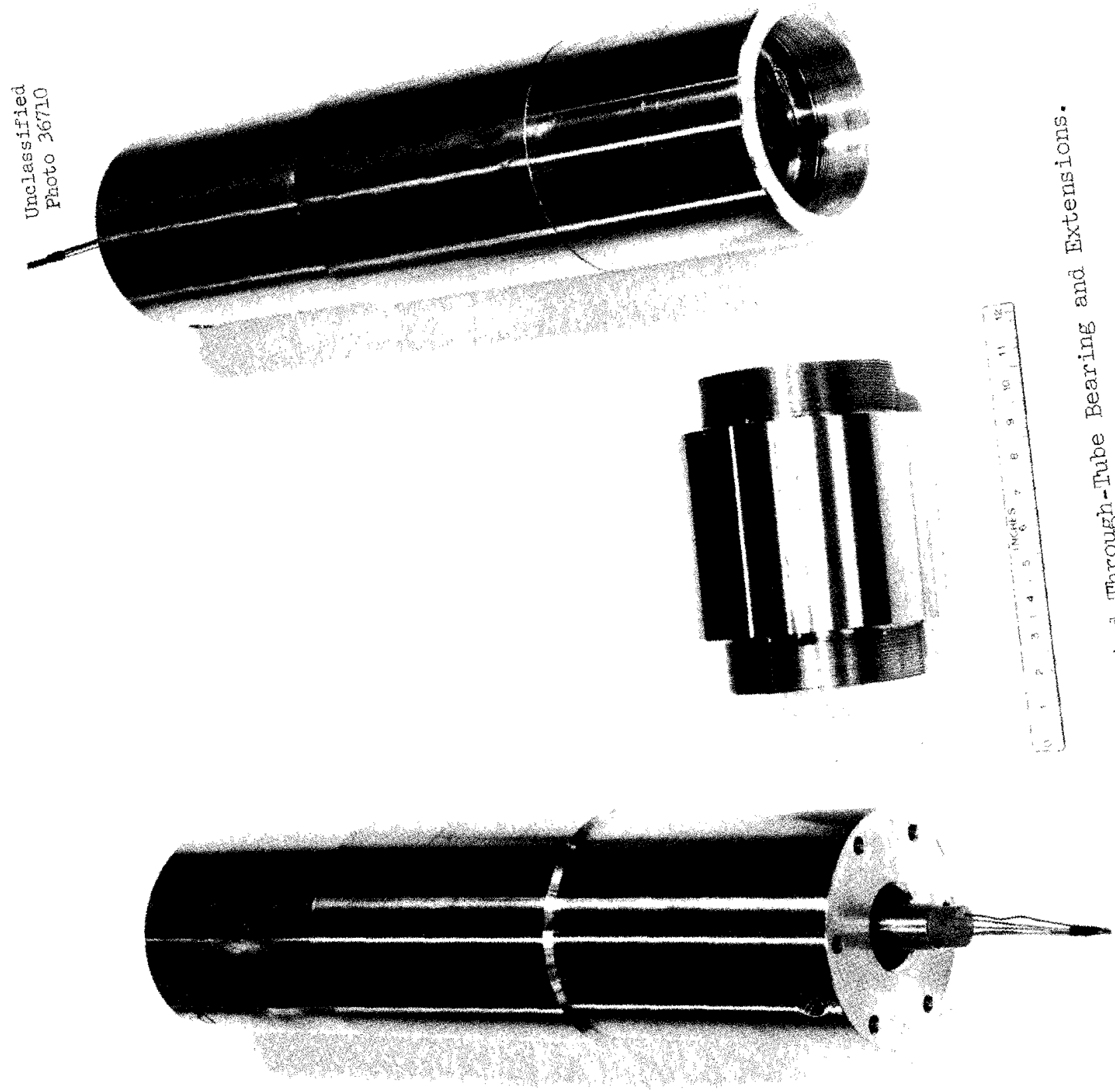

$\dot{m}$ 


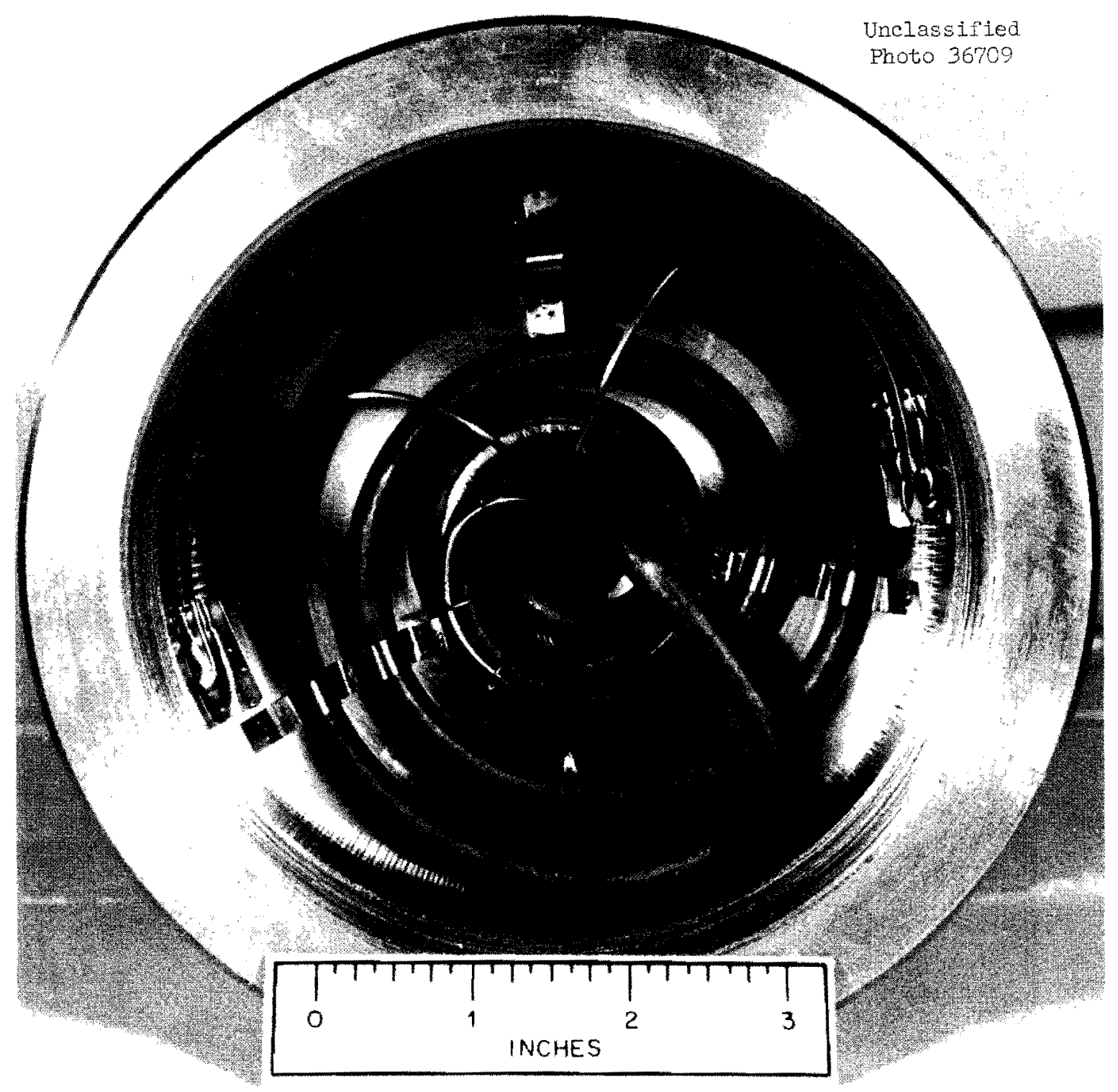

Fig. 4. Heater and Thermocouples for Heating of Plug Extension. 


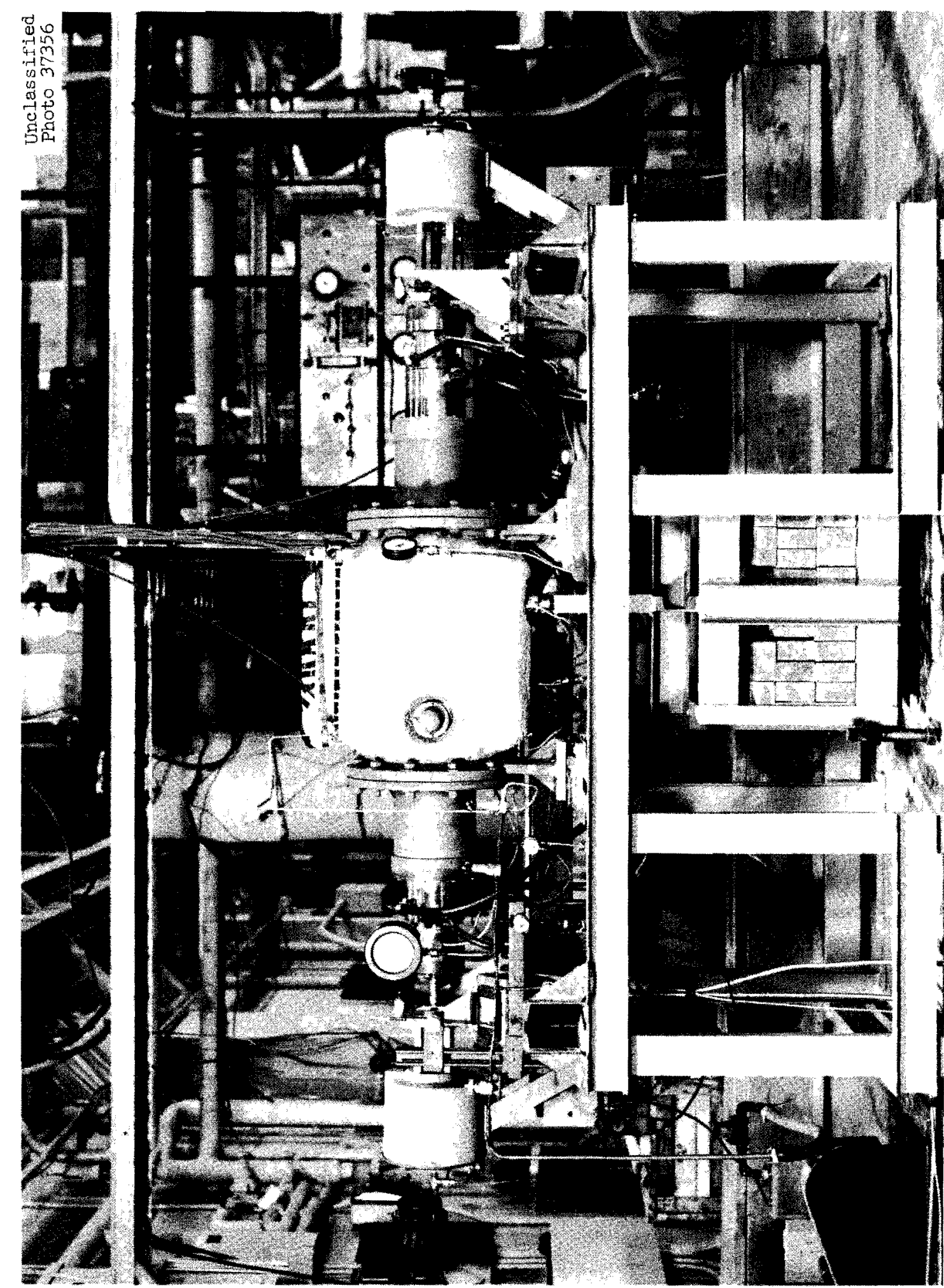


Test Procedure

The plug extensions were screwed onto the plugs, and this assembly was inserted through the sleeve which had been previously installed within the test housing. The housing was closed with the end flanges and purged with helium until the oxygen and water vapor levels each fell below $10 \mathrm{ppm}$ by volume and the total impurity level in the helium was less than $0.01 \%$. Upon reaching the desired concentration, the pressure in the test housing was raised to approximately 2.0 psig and maintained for the remainder of the test. A continuous supply of 1 to 2 cfh of helium was required to off-set the leakage which occurred around the plug extension seals. Typical impurities observed, along with the minimum and maximum per cent by volume observed during the test program, are shown below:

Impurity
$\mathrm{H}_{2}$
$\mathrm{H}_{2} \mathrm{O}$
$\mathrm{N}_{2}+\mathrm{CO}$
$\mathrm{O}_{2}$
$\mathrm{~A}$
$\mathrm{CO}_{2}$

$$
\begin{aligned}
& \frac{o \text { by Volume }}{0.001-0.05} \\
& 0.0003-0.0009 \\
& 0.002-0.04 \\
& 0.0002-0.0008 \\
& 0.0001-0.0005 \\
& 0.0005-0.004
\end{aligned}
$$

Values for all impurities except water were obtained by a mass spectrometer analysis of the gas removed from the test enclosure. Water analyses were obtained by a Consolidated Electrodynamics Moisture Monitor connected to the helium supply line at the test housing inlet gas tap.

The plug and sleeve were heated to $950^{\circ} \mathrm{F}$ before the air pressure was adjusted on the Conoflow operators, and at least one cycle was completed with no load on the test pieces to check the length of travel during each half cycle. Adjustable arms which activated switches and solenoid valves automatically reversed the direction of travel. These arms were located on the side of the plug extensions and incorporated 
the necessary adjustments for limiting the length of travel. Mechanical stops were installed on each Conoflow operator support structure to limit the amount of overtravel in event of a switch failure. After the travel was properly adjusted, a metal basket was attached to the shaft which trensmitted load through the housing to the sleeve. Increments of weight in the form of lead bricks were added at the start of each succeeding cycle until the desired weight (2100 1bs.) had been applied to the test fixture. Pressure on the operators was then adjusted to give an over-all cycle time of 7 to 8 minutes, divided equally between each half cycle, and the 1000-cycle test started.

Upon completion of the cycle test, the parts were subjected to the static load for extended periods of time at $950^{\circ} \mathrm{F}$ to check for self-welding tendencies.

Test Results

Six tests, two on each type of bearing material, were conducted in the test rig. In each test the same type of bearing material was placed on both the plug and the sleeve, and the parts were subjected to the test procedure outlined above. Data on the test materials are given in Table 1 .

Test No. 1, utilizing Stellite No. 6 as the bearing material, was run for 220 cycles at temperature before a seizure occurred between the test pieces and the test was terminated. Inspection of the parts revealed longitudinal scoring of both pieces (Figures 6 and 7) and material removal to a depth of $.070 \mathrm{in}$. on some parts of the plug bearing area. Due to the surface irregularities in these areas, the exact depth of the scoring was questionable; however, it appeared that the original $1 / 16$ in. of bearing material had been removed, and scoring of the stainless steel block had occurred. In this initial test there was a relatively sharp edge on the plug where it came in contact with the sleeve bearing surface. It is possible that this edge could have initiated the observed galling. 
Table 1. Test Materials

\begin{tabular}{|c|c|c|c|c|c|}
\hline $\begin{array}{c}\text { Test } \\
\text { No. }\end{array}$ & $\begin{array}{r}\text { Bearing } \\
\text { Surface } \\
\text { Material } \\
\end{array}$ & $\begin{array}{l}\text { Material } \\
\text { Thickness } \\
\text { Inches }\end{array}$ & $\begin{array}{c}\text { Surface } \\
\text { Hardness* } \\
\text { (Rockwell C) }\end{array}$ & $\begin{array}{c}\text { Surface } \\
\text { Finish } \\
10^{-6} \text { in. rms }\end{array}$ & $\begin{array}{c}\text { Maximum } \\
\text { Loading } \\
\text { los. }\end{array}$ \\
\hline 1 & $\begin{array}{l}\text { Stellite } \\
\text { No. } 6\end{array}$ & 0.012 & 33.5 & 32 & 3150 \\
\hline 2 & $\begin{array}{l}\text { Stellite } \\
\text { No. } 6\end{array}$ & 0.012 & 33.5 & 32 & 3150 \\
\hline 3 & $\begin{array}{l}\text { Linde Flame- } \\
\text { Plate LW-IN30 }\end{array}$ & 0.010 & 60 & 14 & -2100 \\
\hline 4 & $\begin{array}{l}\text { Stellite } \\
\text { No. } 12\end{array}$ & 0.012 & 51 & 32 & 3150 \\
\hline 5 & $\begin{array}{l}\text { Linde Flame- } \\
\text { Plate LW-IN30 }\end{array}$ & 0.010 & 60 & 14 & 3150 \\
\hline 6 & $\begin{array}{l}\text { Stellite } \\
\text { No. } 12\end{array}$ & 0.012 & 51 & 32 & 4700 \\
\hline
\end{tabular}




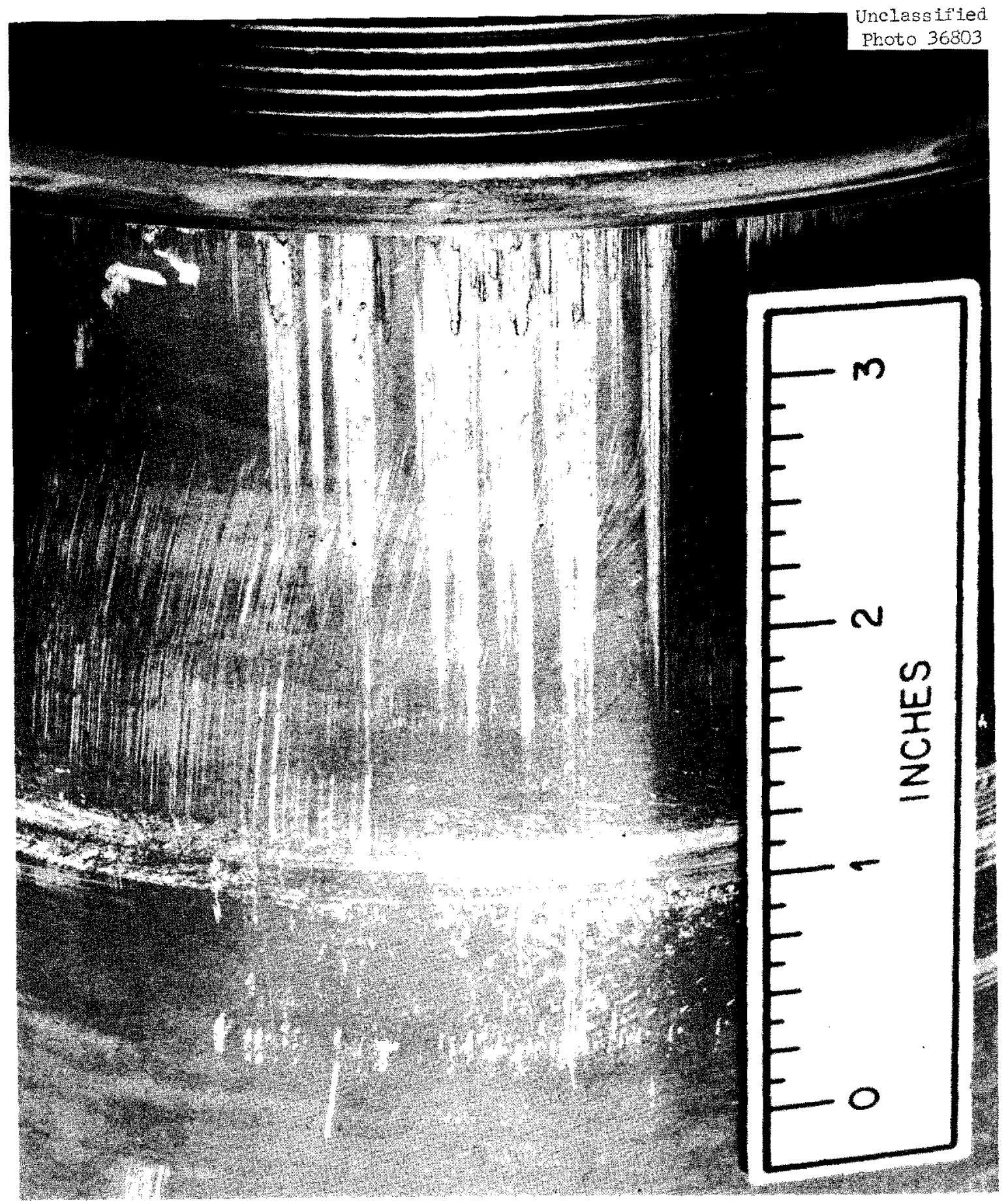

Fig. 6. Test No. 1 Plug, Bearing Material - Stellite No. 6. 


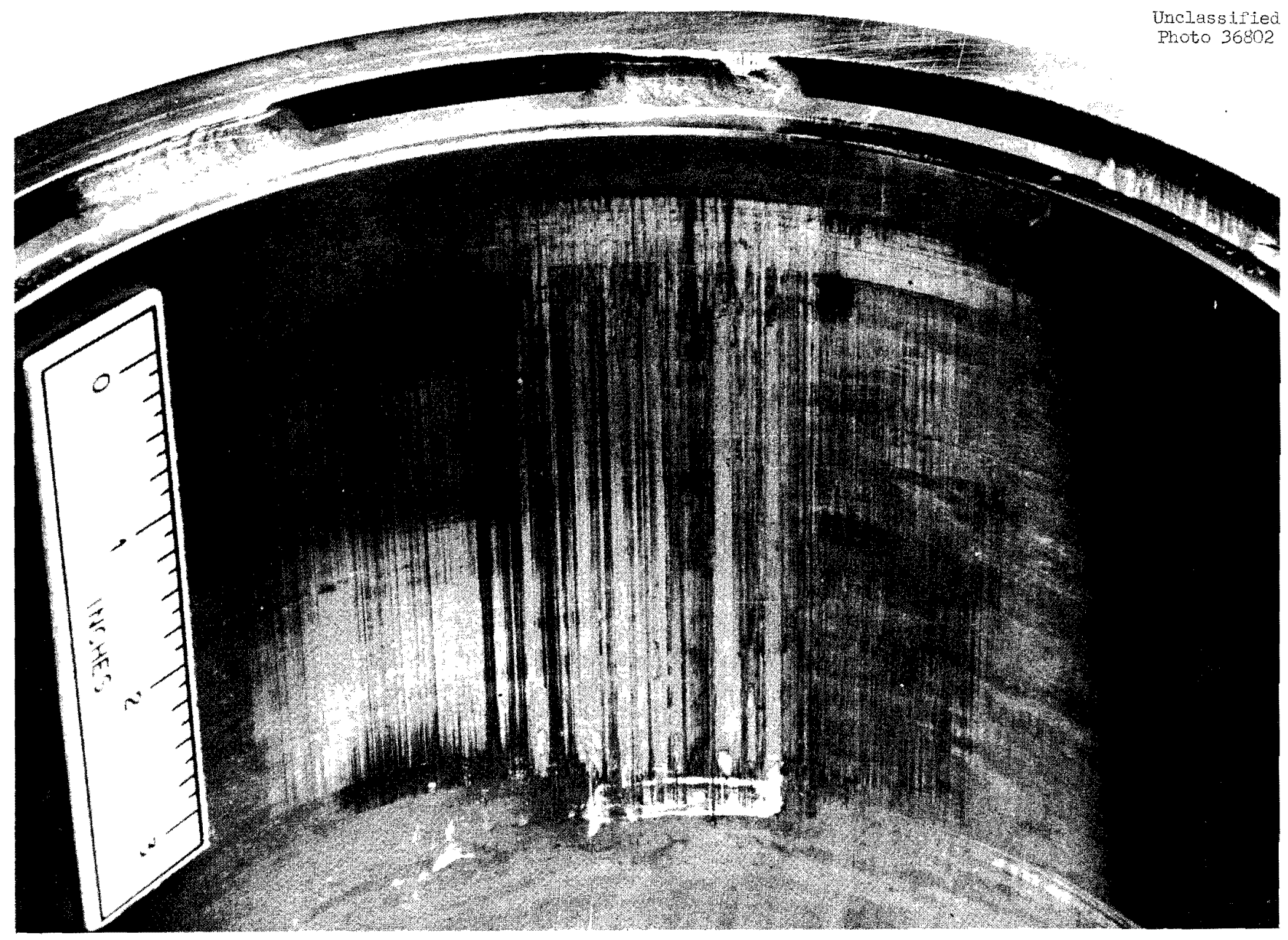

Fig. 7. Test No, I Sleeve, Bearing Material - Stellite No. 6. 
After grinding a $1 / 8$-in. radius on the leading edge of the plug, the Stellite No. 6 was again checked in Test No. 2. For this test the sleeve and plug were rotated $180^{\circ}$ to bring fresh bearing areas into contact. The mechanical cycling test was terminated after 1010 cycles at operating conditions and then submitted to a $168 \mathrm{hr}$ static load test. Pressures required to cycle the plug in the sleeve after $168 \mathrm{hr}$ were identical to those at the end of the mechanical cycling test, indicating that self-welding of the parts had not occurred. Considerable galling was again noted (Figures 8 and 9) during the post-test examination of the parts, and since maximum depth measurements were felt to be inadequate, the metallic particle which could be brushed from the test pieces was submitted for spectrographic analysis. Results of the analyses showed approximately $5 \%$ nickel which would again indicate that the Stellite had been completely removed from some areas and scoring of the stainless steel had occurred.

Test No. 3, using Linde Flame-Plate LW-IN30 as the bearing material, was terminated upon completion of 1009 cycles and a $170 \mathrm{hr}$ period under a static load. The thrust required to move the parts at the end of the static load test indicated no self-welding between the parts. However, examination of the parts after removal from the test fixture revealed a wear pattern different from the previous test (Figures 10 and 11 ) and indicated the parts had not been subjected to the entire design load. Further examination of the test fixture showed that the clevis used to connect the extermal weight to the intemal yoke on the sleeve had been resting on the lower portion of the test housing during a portion of the cycle, and at best only two-thirds of the design load had been applied to the test pieces.

Alterations were made to the test rig to prevent this interference, and the test pieces were rotated to provide a new surface for additional testing.

In the interim period, Test No. 4 was assembled using Stellite No. 12 as the bearing material. After 682 cycles at design conditions, the thrust required to move the parts became excessive, and the test was terminated. 


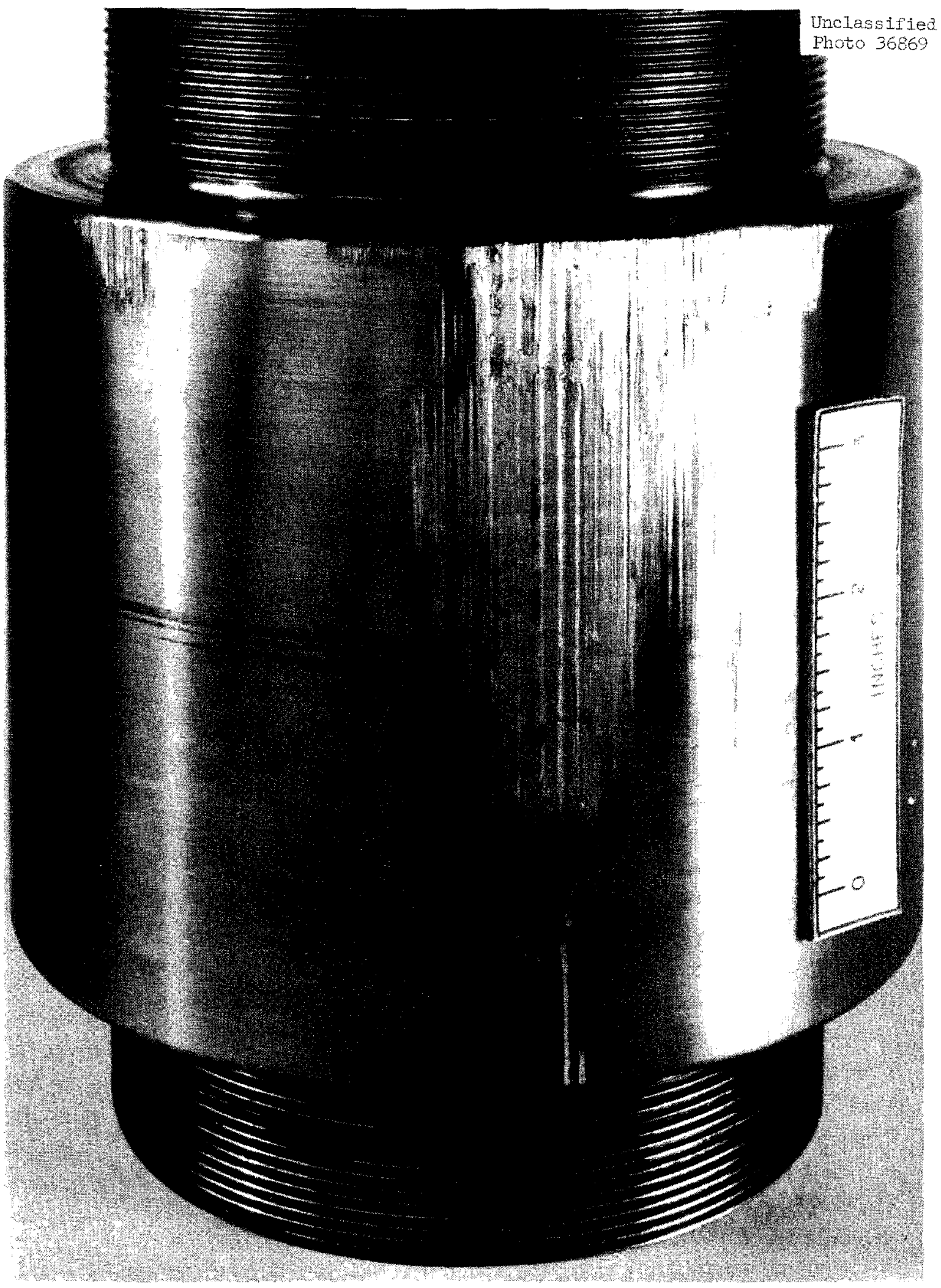

Fig. 8. Test No. 2 Plug, Bearing Material - Stellite No. 6. 


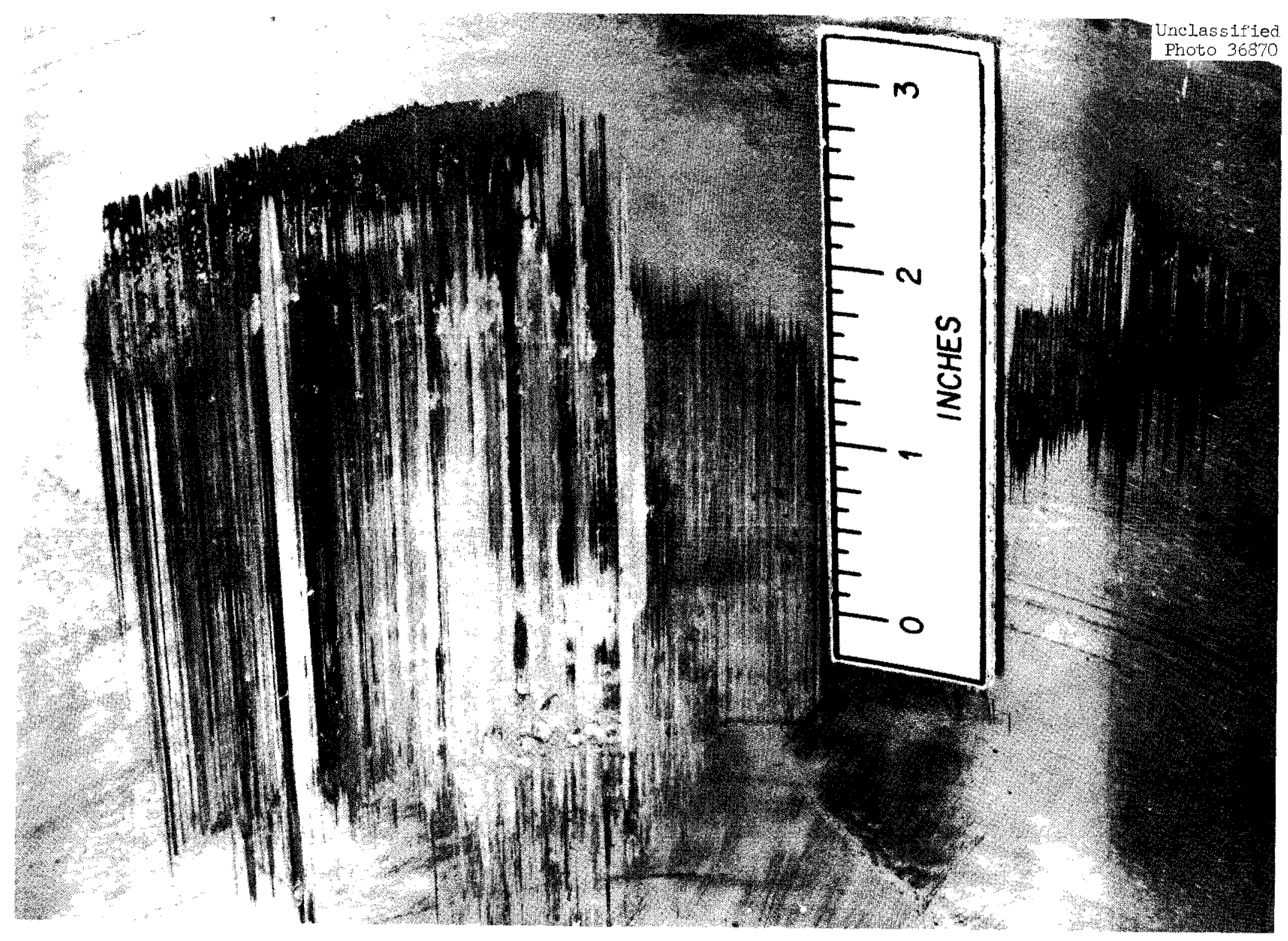

Fig. 9. Test No. 2 Sleeve, Bearing Material - Stellite No. 6. 


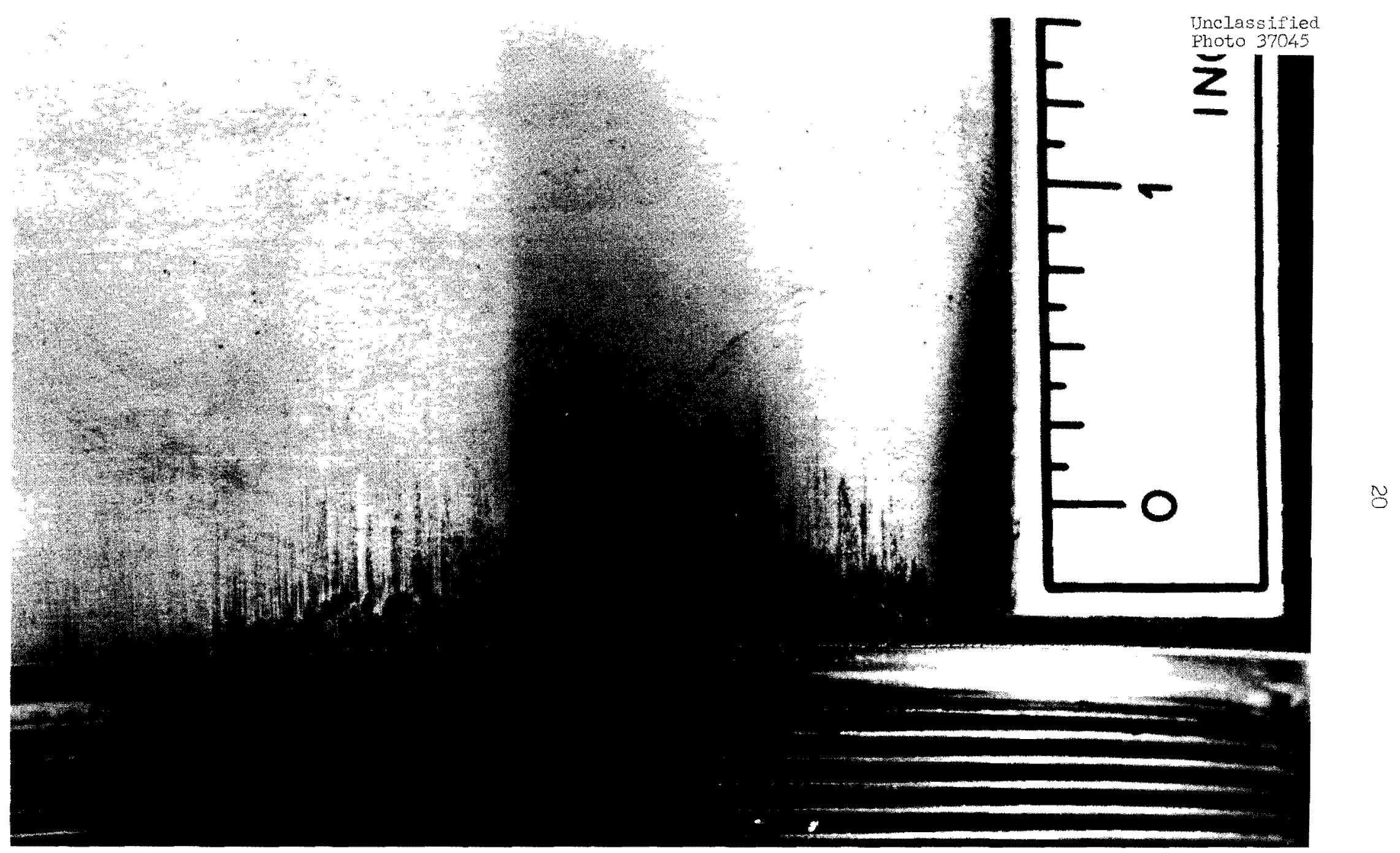

Fig. 10. Test No. 3 Plug, Bearing Material - Linde Flame-Plate LW-1N30. 
Unclassiried

Photo 37046

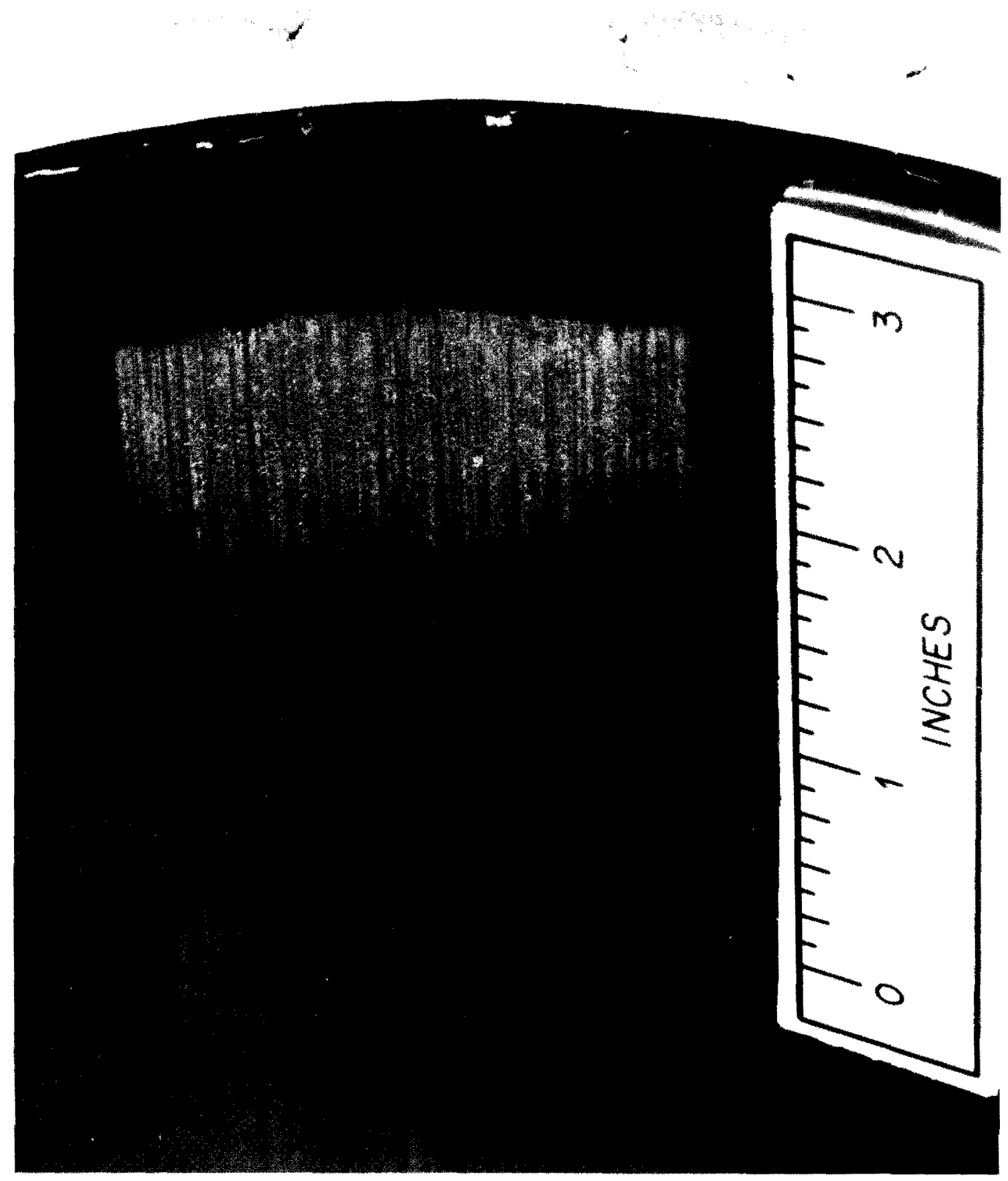

Fig. 11. Test No. 3 Sleeve, Bearing Material - Linde Flame-Plate LW- IN 30 . 
Examination of the test pieces showed some galling (Figures 12 and 13); however, the amount of abrasion was considerably less than that which had occurred with stellite No. 6. The large thrust requirement was attributed to excessive wear in the bronze journal bearings and a resultant misalignment of the plug extensions when subjected to the design load.

Test No. 5 was conducted with the reworked parts coated with the Linde Flame-Plate LW-IN30. After 25 cycles at operating conditions, some seizing and erratic movement of the test pieces was noted during the last one inch of travel on each half cycle. This erratic movement became progressively worse with each cycle until at the end of 350 cycles the vibration developed was enough to move the entire test stand. The test was then terminated and the parts were inspected. Gross amounts of galling and flaking of the Flame-Plate had occurred on both parts as shown in Figures 14 and 15.

The final test (Test No. 6) was run with Stellite No. 12 as the bearing material. In this test the plug had an approximately $0^{\circ} 36^{\prime}$ longitudinal taper ground from the center of the test piece to the leading edge in order that the slope of the plug surface would conform more closely to the loaded slope of the sleeve. Due to the geometry of the test fixture, this modification resulted in a shift in the area of contact between the plug and sleeve. This shift in the point of contact, as determined after the test was completed, resulted in an increase in the maximum beaxing load to a value approximately 1.5 times greater than anticipated in the reactor application. Even under these conditions the parts completed a 1025-cycle test and two static load tests consisting of a 170 and a $850 \mathrm{hr}$ period. Galling was again observed (Figures 16 and 17) on both the plug and sleeve. Measurements taken on both parts showed the maximum material removal had occurred on the plug to a depth of approximately .04 in. The depth measurements were, as before, only approximate due to the surface configuration after the test. 


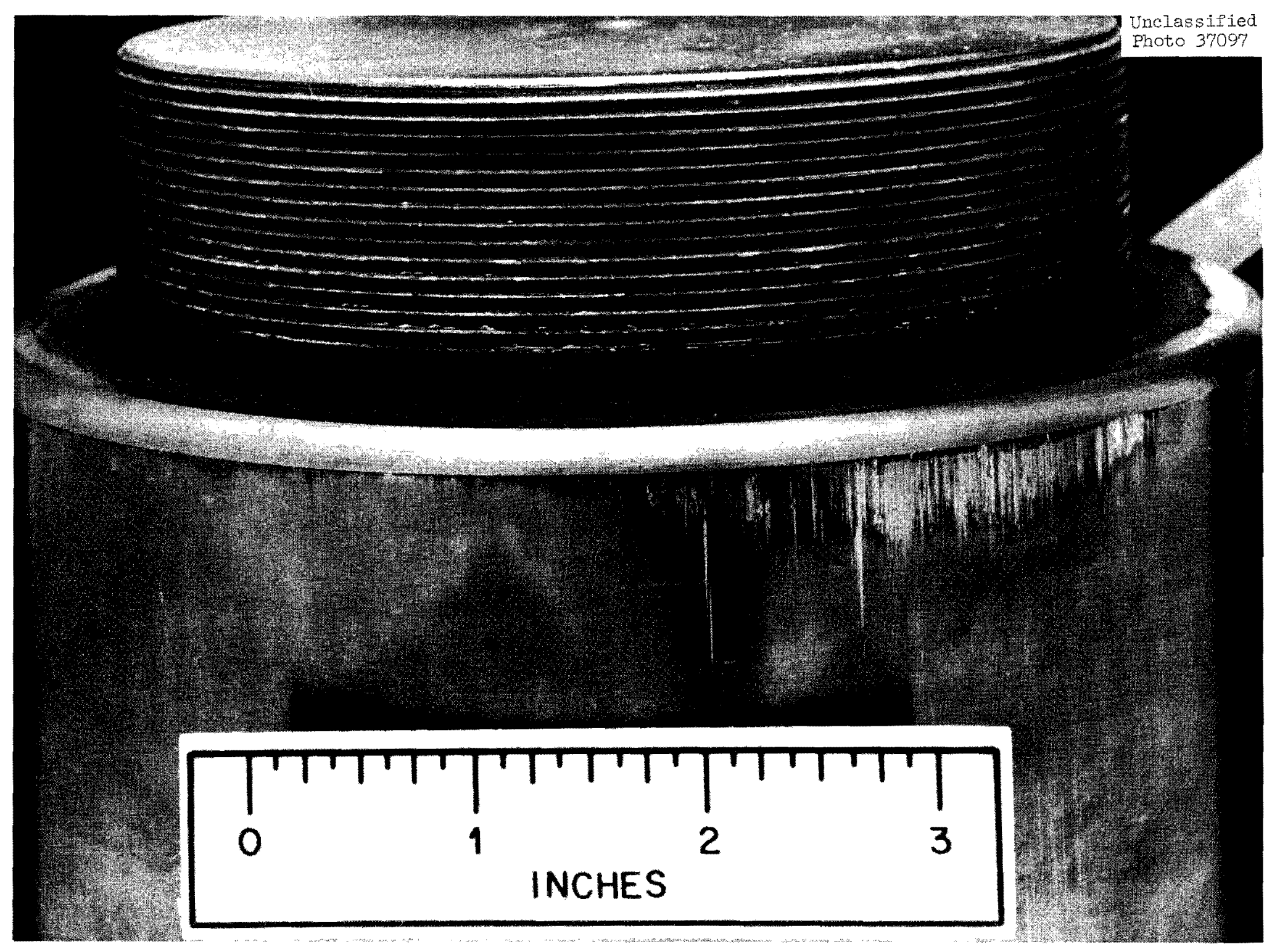

Fig. 12. Test No. 4 Plug, Bearing Material - Stellite No. 12. 


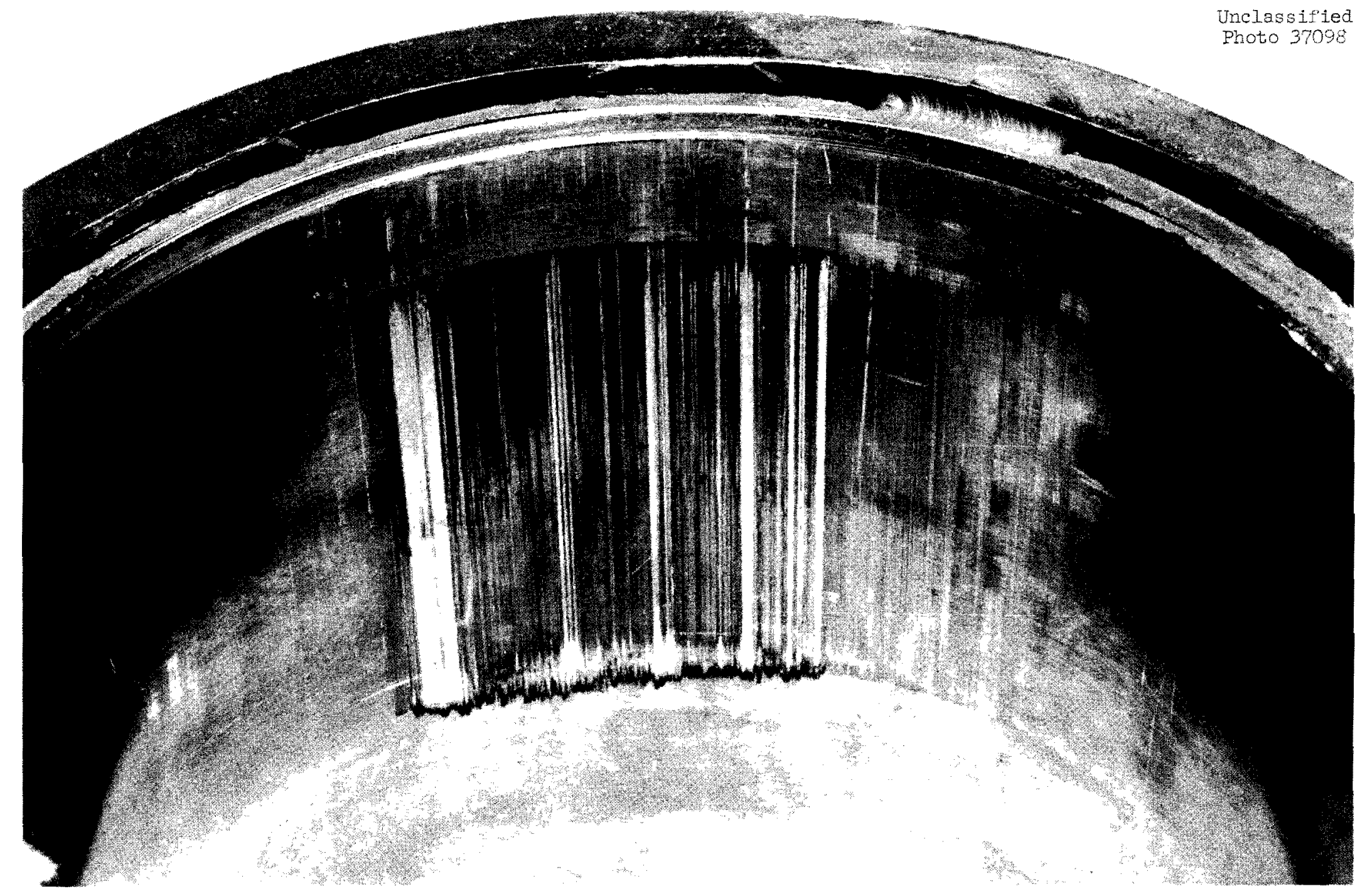

Fig. 13. Test No. 4 Sleeve, Bearing Material - Stellite No. 12. 


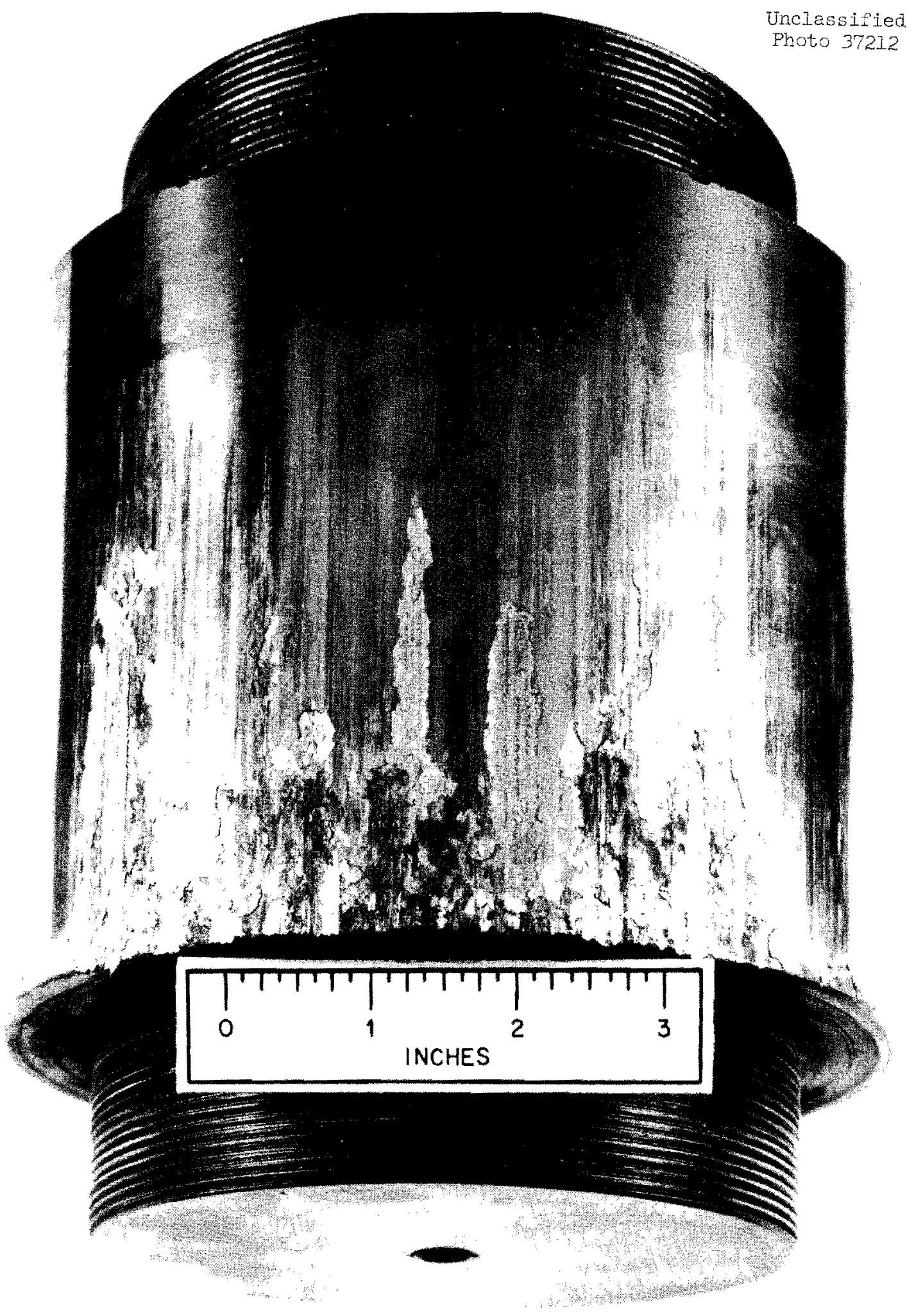

Fig. 14. Test No. 5 Plug, Bearing Material - Linde Flame-Plate LW$1 \mathrm{n} 30$. 


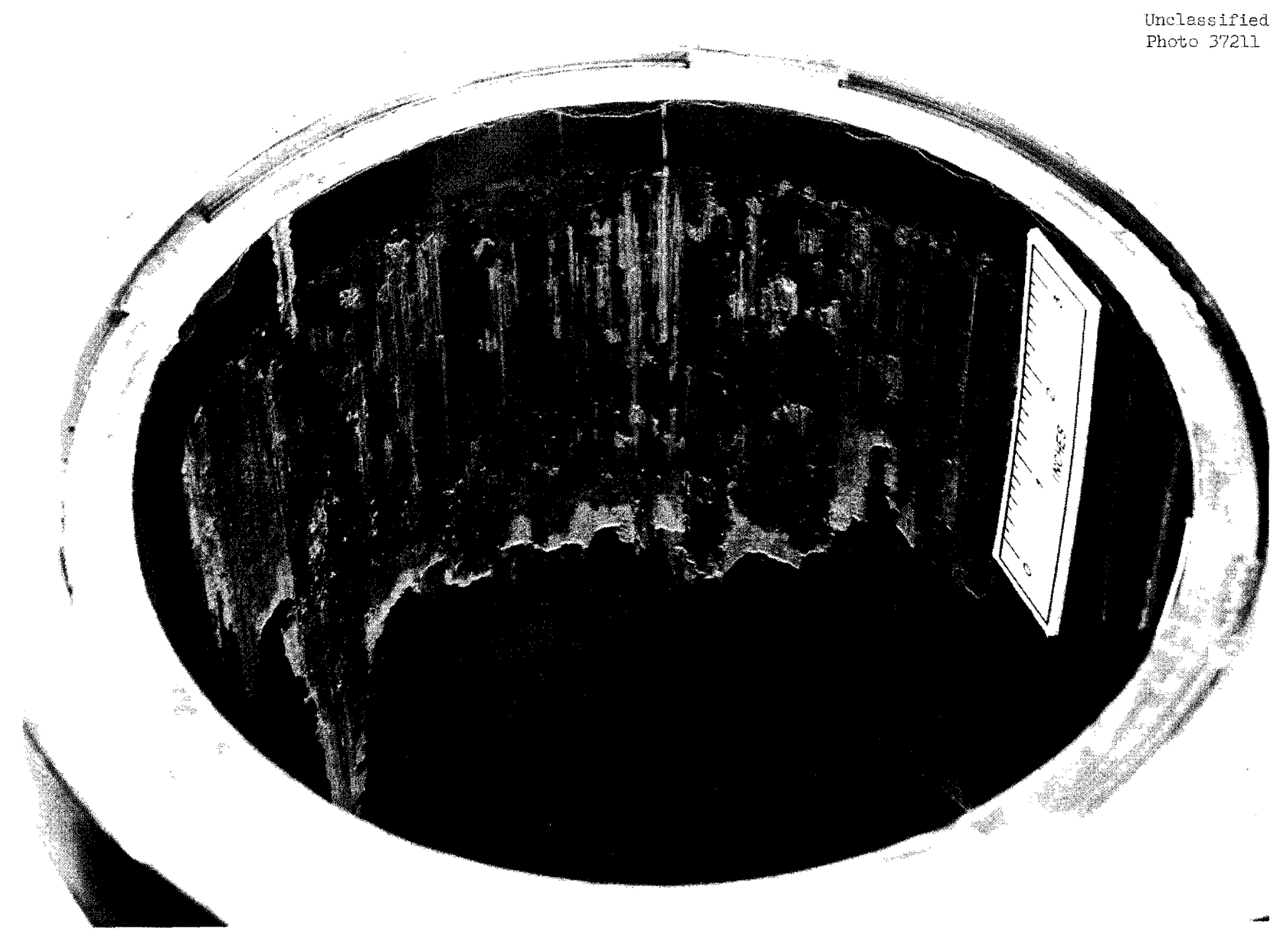

Fig. 15. Test No. 5 Sleeve, Bearing Material - Linde Flame-Plate LW-1N30. 


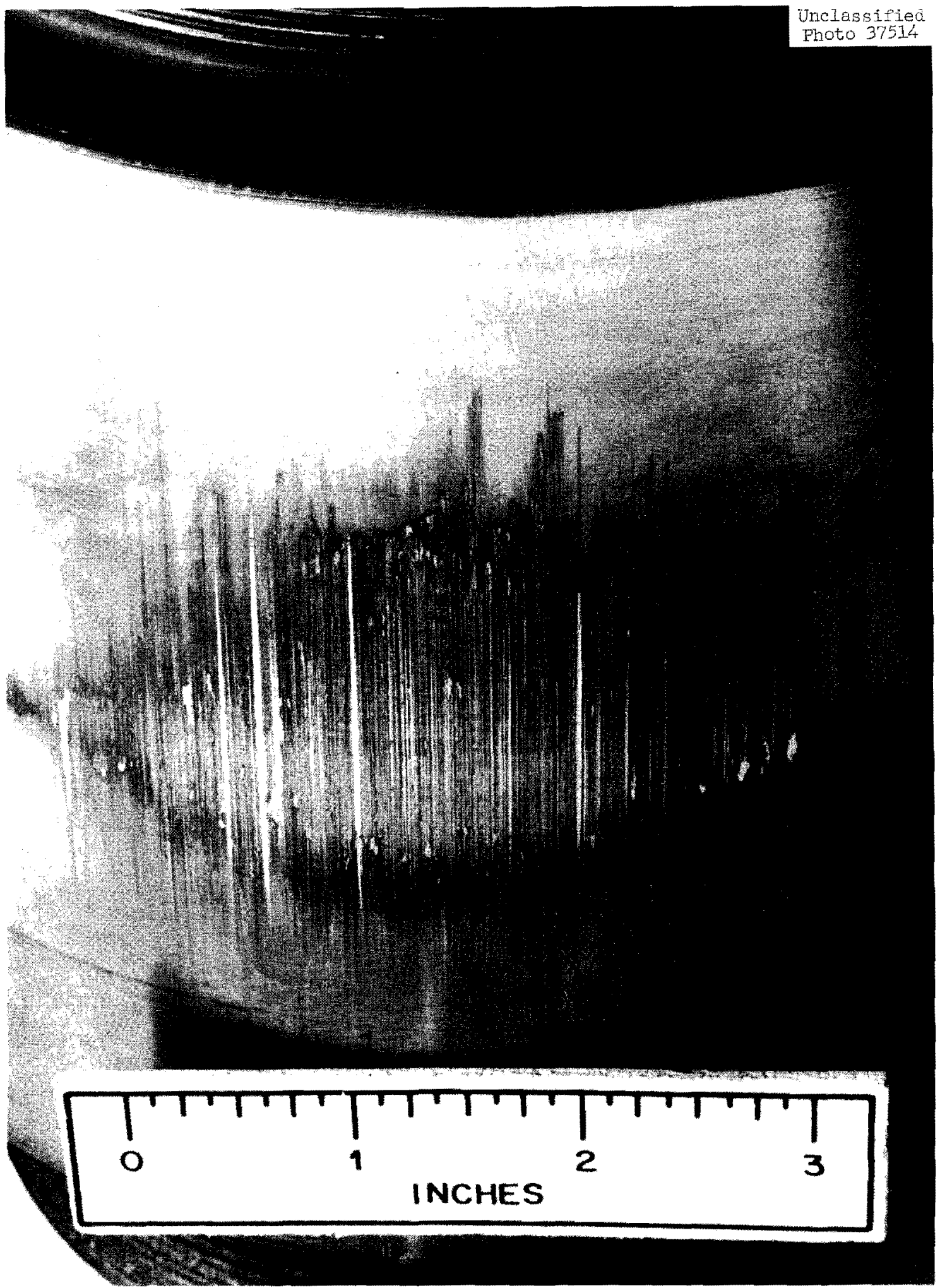

Fig. 16. Test No. 6 Plug, Bearing Material - Stellite No. 12. 


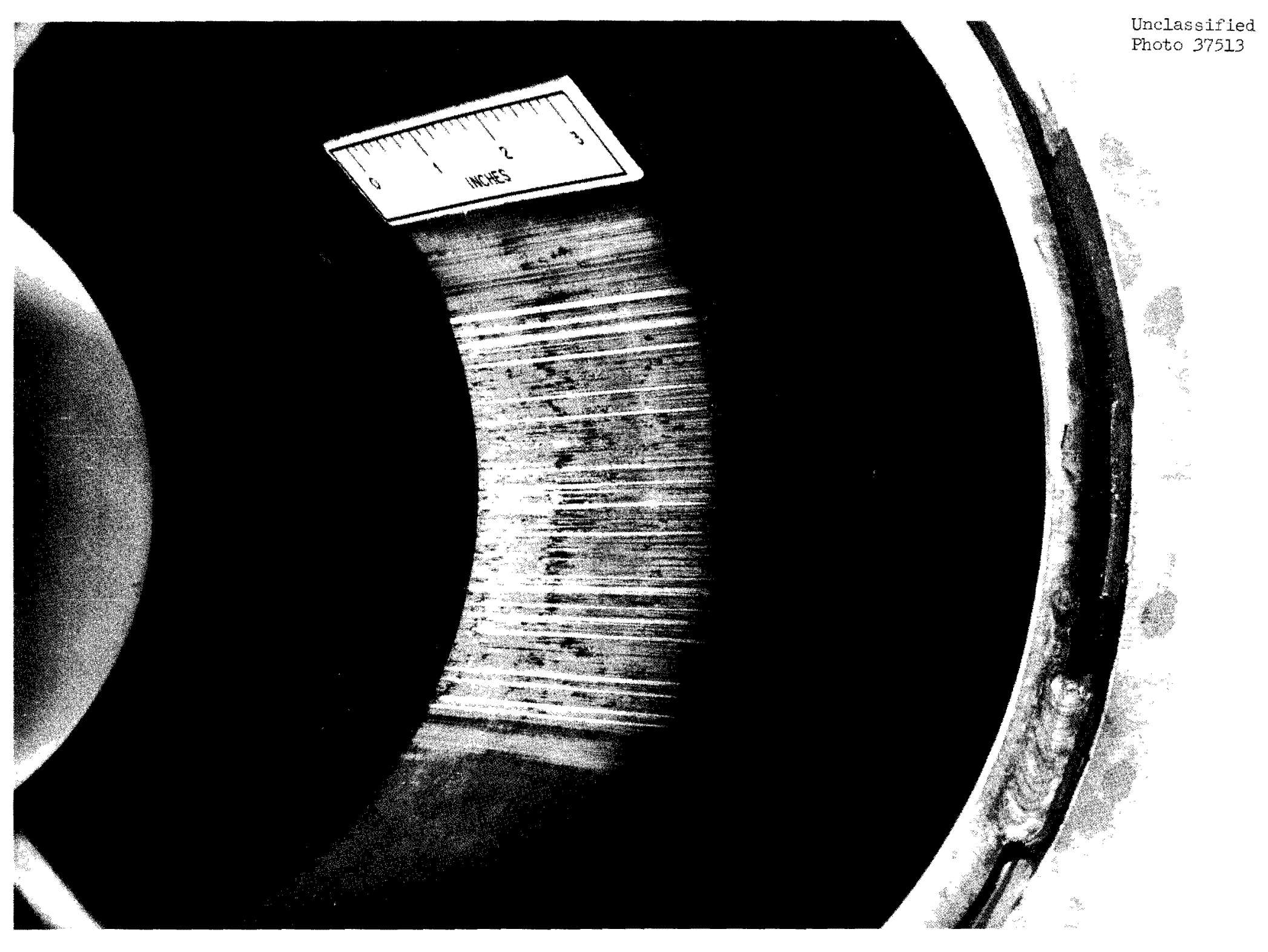

Fig. 17. Test No. 6 sleeve, Bearing Material - Stellite No. 12. 


\section{Conclusions}

Results of these tests which were conducted for more than twice the number of cycles anticipated in the reactor and at a load exceeding design calculations indicate that Stellite No. 12, although showing some amount of galling, would provide the most reliable bearing surface for the intended application. The use of a tapered section on the through-tube bearing surface appeared to provide increased reliability of operation. Stellite No. 6 showed considerably more galling of the surface under less strenuous conditions, and Linde Flame-Plate LW-IN30, due to the gross galling and flaking of the material, would not be recommended for use under conditions of the tests. 

Internal Distribution

I. J. C. Amos

2. S. E. Beall

3. M. Bender

4. A. I. Boch

5. W. F. Boudreau

6. R. E. Briggs

7. D. W. Cardwell

8. W. F. Ferguson

9. A. P. Fraas

10. I. C. Fuller

11. B. C. Garrett

12. A. G. Grindell

13. R. E. Helms

14. T. I. Hudson

15. R. N. Lyon

16. H. G. MacPherson

17-21. R. M. MacPherson

22. W. D. Manly

23. A. P. Marquardt

24. A. J. Miller

25. F. H. Neill

26. A. M. Perry

27. M. W. Rosenthal

28. H. W. Savage

29. A. W. Savolainen

30. M. J. Skinner

31-35. A. M. Smith

36. I. Spiewak

37. E. Storto

38. J. A. Swartout

39. D. B. Trauger

40-47. G. D. Whitman

48. J. Zasler

49-50. Central Research Iibrary (CRL)

51-53. Y-12 Document Reference Section (DRS)

54-56. Laboratory Records Department (LRD)

57. Laboratory Records Department - Record Copy (LRD-RC)

\section{External Distribution}

58-71. Division of Technical Information Extension (DTIE)

72. Research and Development Division, ORO

73-74. Reactor Division, ORO 
